Biannual Research Journal Grassroots

Vol.55, No.I, 2021: 218-231

Grassroots

\title{
THE LIFE AND ACHIEVEMENTS OF HYDER BUX JATOI, WITH AN SPECIAL REFERENCE TO HIS SOCIAL AND POLITICAL CONTRIBUTIONS
}

\author{
Daleel Khan Jatoi \\ Lecturer (Social Studies) Teachers Training Institutions Government of Sindh \\ Email: jatoidaleel1@gmail.com \\ Muhammad Farshad \\ Ph.D. Scholar, School of Foreign Languages, Central China Normal University \\ Email:panhwar.farshad@gmail.com \\ Dr.Uzma Murad Panhwar \\ Assistant Professor, Department of Educational Management and Supervision, \\ Faculty of Education, University of Sindh, Elsa Kazi Campus Hyderabad \\ Email:uzma.panhwar@usindh.edu.pk
}

\begin{abstract}
Comrade Hyder Bux Jatoi, also known as 'Baba e Sindh', was the most prominent leader of the farmer societies of pre-independence Pakistan. Although he was a bureaucrat turned into a farmer activist, but later he played a very important role in the social and political settings of the country at that time. Most of the Pakistani people remember him as a sign of change and renovation in the agricultural history of Pakistan. This was a great effort to credit the frontrunners and their struggle; it is very prominent among the laborers and landless leaders of the world. He devoted his entire life to set peace up for the struggle of land ownership rights to dispossessed farmers, and highlighted the cause, to be noticed by the notables. The vision of Mr. Jatoi is still reflected in many situations when initiatives are taken by the various governments of the world to provide the masses with the basic requirements of development and peace.
\end{abstract}

Keywords: Peasant Rights, Reawakening Movement, Sufferings, Struggle, Achievements

\section{INTRODUCTION}

Comrade Hyder Bux Jatoi was born in the hometown of his ancestors, to landlord Allah Dad Khan Jatoi on $7^{\text {th }}$ October 1901 at village Bakhodero near Mohen jo Daro District Larkana. He had two Mothers Sabaan (real) and Khairan (stepmother). Allah Bux Jatoi was his real brother from his mother he had also one brother Ahmed and two sisters Alam Khatoon and Jamzadi from his stepmother. He had five sons (1) Mustafa Hyder (2) Mazhar Hussain (3) Allah Dad Khan 
(4) Hatim Ali (5) Murtaza Hyder, and thirteen grandsons. His father died in his childhood after that he was looked after under the guardianship of his grandfather and his aunt. On $21^{\text {st }}$ May 1970, he left his mortal world and got rest at the tomb of Mian Ghulam Shah Kalhoro Hyderabad Sindh.

He completed his primary education from his native place village Pathan and qualified final examination in the field of Sindhi vernacular in 1918 and got top position all over Sindh, after that he has taken admission in Sindh Madrasah school Larkana also received the title of the first position from Bombay University in 1923.

After completing matriculation, he was admitted at the D.J. Science College Karachi and completed a bachelor's degree in 1927 and he was awarded two different types of scholarships 15 rupees per month because he topped the entire Muslim community in India and 30 rupees on (open merit) per month on the ground of talent.

The leftist Jatoi had command over various subjects. He was, also one of the leading religious scholars of the time who preached the religious teachings and paid the moral and financial contribution to the benefit of society especially for those who did not survive in our culture, his religious work was exceedingly rewarded by the communists. He was also known as one of the leading communist scholars to the literary community of India. His written work Shikwa stood on high rank as compared to the that of Iqbal's complaints with God (Iqbal's Shikwa) Iqbal paid the apology because he was under the pressure of religious extremists regarding his shikwa. People called him the brave intellectual personality of Sindh. Moreover, his review of the Holy Quran is highly appreciated. He is labeled as an eminently political and social symbol of Sindh. Hyder Bux Jatio was made their associations with some political parties like a communist, congress, and theosophical society. Jatoi left his permanent job as Deputy Commissioner (DC) and joined the Sindh Haari committee in 1943 and frolicked the fundamental role against the capitalist system of landlords.

\section{HYPOTHESES}

1. Hyder Bux Jatoi made great social and agricultural achievements.

2. Hyder Bux Jatoi contributed immensely to the Politics of Pakistan.

\section{QUESTIONERS}

1. What are the major achievements of Hyder Bux Jatoi?

2. How did Hyder Bux Jatoi contribute to the Politics of Pakistan? 


\section{OBJECTIVES OF THE STUDY}

1. To analyze and highlight the achievements of Hyder Bux Jatoi

2. To identify and point-out the political contribution of Hyder Bux Jatoi

\section{SIGNIFICANCE OF THE STUDY}

This research work will try to clarify the role played by Hyder Bux Jatoi in his life, especially in social, agricultural, and political contributions. This research article would also be a port of good contributions to academic, social, and political circles. This article would be open up new paths to be explored, which were not explored before.

\section{RESEARCH METHODOLOGY}

Research is based on Mixed Method research design. It is based on sources of primary and secondary sources, which are interviews and through the reading of related books, magazines, news articles, and research papers, respectively. Being a student of social science, it is very necessary to analyze and look at the deferent points of view in various steps from history to understand the path of social activist pursued by Hyder Bux Jatoi, who carried out to result-oriented struggle for the benefit of the peasant community.

\section{DATA COLLECTION}

This data is collected by two main sources, primary and secondary data, using many different tools.

Primary Data: Interviews were conducted with relevant people like Mr. Azhar Ali Jatoi, junior Hyder Bux Jatoi, Professor Dr. Dur Muhammed Pathan owner, and director Gul Hayat Institute Arija taluka bakrani, Professor Dr. Amir Ali Chandio, Chairman, Department of Political Sciences, Shah Abdul Latif University, Khairpur.

Secondary Data: An in-depth study, and thorough reading of research articles, books, papers, pamphlets, and newspapers, or any written collection material from various websites, institutions, and public libraries. The secondary source was carried out so that the study may be kept unbiased, when reading it from the dissimilar point of view and examines them neutrally. 


\section{LITERATURE REVIEW}

Haari Inqilab (1953) the book regarding Haari renovation was published in 1953, Hyder Bux Jatoi brought attention to the different problems and issues related to the peasantry class. He showed the real picture of issues from the mirror of history how the societies suffer? and finally, how they can get relief with economic and social protection. In this book, the peasant rights were reflected and it clearly defined that the societies were developed through the power and the strength of peasants. In Haari Kahanyoon (1950) the writer explained the clear argument to return the resources of agriculture's to peasants and he suggested changing the mindset of the Public against the Zamindars.

Making of modern Sindh (1999) the author explores the traditional administration system of land revenue. It had been described in the clear figure of 1885 that the system was implemented like LAPO, OTAQ, RAJ BHAG. These were the share system of the property owner, which were paid by farmers to the landlord for the occasion of death, disease, flood, marriage, village welfare fund, religious activities, and visit guests at the guest house of zamindars.

Another burning issue was that of the distribution of products, which were cultivated by farmers, and divided amongst the farmers and property owners (the three percent of products be paid as a share of the proprietor and the remaining one percent was to be paid to peasant throughout the year). It was one of the greatest achievements of Hyder Bux Jatoi to emphasize the campaign in all the major cities of the country to make farmers aware of their equal share of production between property owner and farmer. Although Mr. Jaoti belonged to a high Landowner (Zamindar) family, he supported getting a $50 \%$ share of product to peasants, though there is a hundred percent contribution of farmers to cultivated productions in the world.

The Russian Revolution and the Indian Patriots (1987), this book gave a huge focus on Sindh Haari Committee. The author has stressed to communicate the feelings of the wisdom of co-ordination between the underprivileged peasant against the landlords.

Sindh Haari Committee successfully worked on the grievances of peasants that were created by the Landowners deliberately, since the periods of Kalhoras, Sardars, and Mirs. The difficulties of the farmers increased with time. All the leading classes had the advantage to introduce their policy and plan for the distribution of crop production 
but $1 / 4$ was a common practice of zamindars. Mostly the land of Sindh was under the documentary control of Landlords, they were the main beneficiary of farming land, they collected a major share of production from farmers it was the main source and survival of property owners in Sindh.

The lands of Sindh: who should own them? (1957), the writer had command on the elaboration of the true figure of reasons for uprising paid by peasant class. The unity was brought amongst different protesters spread all over the provincial domains were the main characteristic of this uprising.

The elite class of our society was very much concerned, they played a major role in making divisions and creating fractions in the farmers' society. The elite class society also worked so hard to make the plan to eradicate as speedy as likely for the joint and common descent of all persons. Mr. Jatoi made it publically understandable, the danger that was the main interference in the success of objectives. Muslims and Hindus of the Subcontinent formulated an alliance, to counter the challenges created by The British Raj. The colonialism was on its topmost to exploit the resources and labor of the peasantry class of Muslims and Hindu societies. Finally, they were used to the same track for making the union that was mandatory for the benefits of the general cause.

The British raj vastly manipulated the economy and the system of the Sub-continent. The survival of peasants and local people were in the hands of landholders, actually who had a fear to lose their keen interest because of this they had openly opposite to uprising of peasants. The demands of the feudal lords and their British colleagues were already accepted by common people. The masses were already affected due to the high influence and power of Landlords. The export and imports, the price of agriculture, and trade markets were occupied by the government which consisted of the feudal class. The resistance was very difficult against the highly powerful Landlords, but when prices, taxes, and rates of goods, living costs, agriculture, cultivations, and taxes were increased and the situation was very critical, it was the turning points of the peasant and poor community to start the movement against the elite class. Galyun Goth Wanan Joun (1981:354-55) Peer Hisamuddin Shah Rashdi clearly explained to Soofi shah Inayat Shaheed's slogan that first time was introduced in 
South Asia JO KHERE SO KHAE Soofi Shah Inayat Shaheed also was a reformer he introduced agricultural reforms in the regime of Mughals empire

\section{BACKGROUND}

The region of South Asia has massive agricultural lands. People here are either farmers or Landlords for the maintenance of their survival. The many acres of land were divided into highly rich families, Inayat Shaheed's family was also one of the beneficiaries. When he returns from India to Sindh after 25 years than he openly announced that the farmers are actual owners of the land, the lands are granted by Allah Almighty, and the peasants are the cultivator of it in the real sense. In 1950 the government found a law committee (popularly known as the tenancy Legislation Committee) to recommended the demand and suggestions of the Haari committee. In the same year (1950) the tenancy act was passed by the government of Sindh. It was passed through the struggle and leadership of Hyder Bux Jatoi when he was president of the Sindh Haari Committee.

\section{Achievements of Hyder Bux Jatoi}

The varieties of accomplishments of Hyder Bux Jatoi have appeared in the details of his successful life which also shows his intellectual personality. He provided his valuable services in every field of life like a public servant, journalist, anti-martial law activist, and poet, his career is defined by intellectuals, Haari workers, writers, politicians, and those who are keenly related to lands and revenue. All his achievements are explained in detail.

After completion of his education, he resumed his duty as a clerk in the revenue department in 1928, in 1931 due to his efficiency he was promoted to the upper seat as Mukhtyarkar in the same department. In 1941, he passed the competitive examination, was appointed as DC in the colonial government in India, and performed his duty until 1943.

In 1943 Mr. Jatoi rendered his resignation from collectorship and joined Sindh Haari Committee. The resignation of Mr. Jatoi was yet to be approved, the Hurr movement was in running position peer Sibghatullah Shah Saani (Pir Pagara) was arrested and hanged by the British government it was a very critical situation in Sindh. In this condition as a Sindhi leader, the collectorship was so difficult then he 
decided to resign, but permanent members of Hur Tahreek and followers of Pir Pagara mostly claimed that Hyder Bux Jatoi was keenly involved with the martyr of Pir Pagara, but there is no written evidence found, nor heard.

Hyder Bux Jatoi explained several times that he was closely related to peasants during his job careers in the revenue department also he was an eye witness to the scenes where peasant lives were being destroyed by landlords and illegal orders were imposed on farmers, in this situation he decided to resign and join Sindh Haari Committee.

\section{The Great Poet and Author of Revolutionary Literature}

The great literary figure and great political leader of India (Sindh) Hyder Bux Jatoi was very much a popular poet and writer. He wrote many valuable books he wrote numerous books, poems, and pamphlets on various issues of peasants and the spirit of society that writing work reflects his keen interest in the matter of peasant and poor community and motherland as well.

The 'Sikwa' (The Grievances) was written by Hyder Bux Jatoi on the model of Allam Iqbal's 'Shikwa', Sindhu Darya (Indus river), and Azad-e-quom (independence of nations) were permanent figures of Sindhi literature. The popular slogan of Sindhi nationalist 'Jeay Sindh, Jeay Sindh' was taken from his famous poem 'Jesy Sindh Jeay Sindh Jam-e- Muhabat Peay Sindh'.

TABLE-1

\section{POETRY BOOKS WRITTEN BY HYDERBUX JATOI}

1. Jeaye Sindh Jeaye Sindh

2. Sindh Pyaaree

3. Azadee-e- Qoum

4. HarreeGeet

5. Tofa-i- Sindh

\section{Journalist}

Haari Haqdar's weekly newspaper was published in 1945. It particularly favored the peasant community. Another newspaper was KISAN Jatoi advocated the legal rights of peasants through print media all over Sindh these newspapers were legally supporting peasant and 
all their issues. The support was easily communicated through print media, all the messages, meetings, party programs, and other matters of the Haari movement.

\section{The Role in Politics}

In the year 1943, Hyder Bux Jatoi decided to surrender his job, which was on a high position in the British government in India and joined Sindh Haari Tahrik (Sindh peasant rights' movement) to eradicate the cruelties of Landlords with the poor and peasants. Hyder Bux Jatoi and some other Haari workers participated in local as well as in general elections all over Sindh, unfortunately, they could not win their seats because of the high influence of Landlords, the most of them were peasants of Landlords.

\section{Haari Movement}

In 1920 the Kissan Bureau was established for authorizing peasants to claim their rights which were not be given by Landlords. In 1930 the Haari conference was held at Mirpurkhas. Sindhi leaders Jamshed Mahta Parsi, Gokhly, Sain G M Sayed, Shaikh Abdul Majeed Sindhi, and Jeth Mal Pursaram participated in the conference and they formed a Sindh Haari Association. They announced their meaningful party agenda publicly; the main three points are as under:

1. Peasant empowerment to be ensured, by giving their ownership rights.

2. The particular portion of cultivated land for a given period; those lands would be allotted to the Farmers.

3. Association also decided the membership fee to be only one Aana, if anyone wants to be a member of the association should pay the required amount.

Slowly and gradually, the name of the Sindh Haari Association converted into a Sindh Haari Tahrek and later into Sindh Haari Committee.

After he resigned from the topmost rank of the colonial government, Mr. Jatoi joined the Sindh Haari movement and was elected as president in 1945. Under his leadership, the committee received a top position and played a dynamic role, and achieved success for the benefit of peasants and common people. Jatoi produced the new and revolutionary slogans "Haari Haqdar", land for landless 
and reintroduced in the new shape of Sufi Shah Inayat Shaheed's slogan "Jo Khere So Khae" as well as the many new strategies were brought by Jatoi which was a benefit for the betterment of committee. Under the Presidentship of Mr. Jatoi, the committee regularly started the protest and demonstration to the elimination of fear and pressures from the thoughts of peasants which was fitted by landowners

On April $4^{\text {th }} 1950$ the Sindh Haari Committee with its 15,000 leaders and members marched to Karachi Sindh and organized a sit-in in front of the Assembly building and moved a bill and the government passed the Tenancy act called "Sindh Tenancy act 1950". It was one of the greatest achievements of Hyder Bux Jatio.

TABLE-2

BOOKS RELATED TO HAARI MOVEMENT WRITTEN BY HYDERBUX JATOI

1. Lands in Sindh, Who should own them?

2. Injustice, the land assessment rates in Sindh

3. Injustice to land tax in districts in Sindh

4. Disposal of evacuee properly part I and part II

5. Disposal of Guddu barrage state land

6. Higher land taxation in Southern part Part I and II

7. Haari Kahanyoon

8. Stop Settlement of the population from Mukhee Dandh Area (1967)

9. Sindh Assembly Election Petition

10. Bill to amendment Sindh Tenancy Act

\section{Anti One Unit Movement}

After the establishment of Pakistan, it was the first time the One Unit was imposed on $5^{\text {th }}$ October 1955 in the ruling period of Prime Minister Muhammad Ali Bogra. The Haari Committee decided to agitate against the decision of one unit because the one unit formula was against the small units like Sindh and Balochistan. In 1955, Sindh Haari Committee started a movement called the anti-one unit movement the Pakistan government issued the arrest warrant and Jatoi was sent to jail.

In 1967 Haari Committee passed a resolution against one unit. Prominently, comrade Jatoi published a meaningful pamphlet "The one-unit and democracy" in 1962. In this pamphlet, Hyder Bux explained the main points regarding one unit, which are as follows:

1) Violation of Press Media in Sindh

2) The disaster of Secondary Education in Sindh 
3) Restricting admissions for Sindhi students in Institutions of Sindh

4) Partial land taxes

5) Blockage of progressive schemes in Sindh

6) Non-recognition of Sindhi Language

7) Procession of lands of Sindh immigrants

8) Eradication of Sindh from world map

\section{TABLE-3 \\ BOOKS WRITTEN BY HYDERBUX JATOI AGAINST ONE UNIT}

1. Democracy or dictatorship in Pakistan part I and part II

2. Democracy and justice of chief justice

3. Shall the Sindhi language stay in Karachi or not?

4. Break One Unit

5. Injustice to Sindh

6. One Unit and Democracy

\section{Allottee Movement}

In 1957 about the seventeen thousand farmers came in front of the president's house, they demonstrated the demands of their rights in the movement led by comrade Hyder Bux Jatoi. Haari committee demanded to allocate the lands to poor farmers, of lands that were left behind by Hindus after the establishment of Pakistan but unfortunately, the president of Pakistan General Ayub khan allotted all the assets of Hindus to immigrant Muslims who migrated from India after partition it was called Allottee movement. As a result, the allottee movement was not a success due to a lack of government interest.

\section{Anti Martial Law Movement}

October $7^{\text {th }} 1958$ the martial law was imposed by the government of Pakistan, and all political parties were suspended and banned containing Sindh Haari Committee, huge numbers of farmers, workers, and leaders were frame charged and they were sent to jail soon after they were released from jail but all the activities of Sindh Haari committee were remain suspended.

Hyder Bux Jatoi was released in 1967 after that he called a large meeting at Hyderabad, where so many resolutions were passed against Ayub khan's Martial law and in the favor of agricultural reforms. 
On $25^{\text {th }}$ March 1969, Yahya khan imposed Martial law, and Pakistan was faced with critical conditions Yahya could not face the political pressure, and soon after the general election of 1970 was announced by Yahya khan.

In the election of 1970 the new political party PPP was Presented a new slogan food, cloth and shelter "Roti Kapraaur Makan" was the most gorgeous and shortcut pathway to the success of life, local and poor people. Especially, farmers were interested to celebrate programs and got sigh under the umbrella of a new political party, many workers of Sindh Haari Committee left and joined to Pakistan people's party and this party raised as a powerful political party in west Pakistan and Haari Committee admitted crises and downfall in Pakistan.

\section{CONCLUSION}

When the research is conducted on any aspect of a famous personality then it is analyzed, therefore it is very hard to cover every aspect of their life, like personality, social, cultural, political, and religious background, etc. Hyder Bux Jatoi was a prominent personality of Pakistan, especially Sindh, who competed for the fundamental role in every part of life. He devoted his life to the reformers of peasants and the lower middle class. In the Allottee and Haari movements, he tried to all people of Pakistan aware of getting their rights from the landlords and feudal class. However, Mr. Jatoi played a significant role against martial law and he started the result orient movement for the abolition of one unit and martial law and his struggle was very much appreciating able to the resettlement of democracy in Pakistan. He spread their message through print and electric media throughout Pakistan and got credit to highlight the burning issues, transforming the committee's complete protest, and leading the movement in the media as well.

The committee got a benefit for increasing membership of about 160,000 in 1948. Haari committee submitted the bill in Sindh Assembly in 1950 and this bill was approved it is called the Sindh Tenancy act of 1950.

Hyder Bux Jatoi proved his title as a comrade to be true as a real friend of people. In many gaits of life that he was certainly dedicated to his concept and he proved himself as a committed leader of the powerless people those were suffered from the injustice of feudal culture, powerful society, and cruel system of landlords for centuries. 
Hyder Bux Jatoi was an eyewitness of unfair sharing of manufacture between landlords and cultivators he explained that the Landlord took the sufficient share in the shape of OTAQ, LAPO, BATTAI PUNJ SAMI, AND RAJBHAG the remaining share was distributed among the Landlords and farmers so it was insufficient to make the balance of peasants and their lives. He again elaborated the situation of poor's that they might be involved in the criminal activities and would be faced fatalities of fears which were affected to their socio-economic progress, beggary, looting, and robbery would be increased in society due to facing of multiple challenges to run their lives.

The struggle of Hyder Bux Jatoi was greatly favorable to settle the prosperity and peace in a society that was proved to mile tone for the betterment of humankind. The approval of agricultural reforms and equal share system of productions and approval of Sindh Tenancy act of 1950 are the biggest achievements of Hyder Bux Jatoi. The agricultural society depends on agricultural products and agricultural farming, the peasants are getting an equal share of their due rights till today, this act would be known countless assurance and devotion to the safety of civilization. Mr. Jatoi's struggle justifies gratitude and his lifestyle and work are still known in best words by not only peasants but also by the well-read class of our culture. The name of Comrade Hyder Bux Jatoi would always be remembered and admired by farmers.

\section{REFERENCES}

Allana, G.A. (2010). 'Sindhi Society and Culture', Sindhica Academy, Karachi, pp.232-234.

Arisar, A.W. (2000). 'Sirr Ji Sadaa Sur Men', New Fields Publication, Hyderabad, Sindh, Pp.15-22.

Bhatti, A.S. (2000). 'Larkano Ammar Shakhisyatoon', Larkana Research Academy, Karachi, pp.70-76.

Bhatti, A.S. (2015). 'Larkana Leaderoon Ki Dharti', Larkana Research Academy Karachi, pp.138-148.

Chandio, S.K. (1996). 'Jinnah Khuhro Correspondence', Sindh Historical and Cultural Publication, Islamabad, p.122.

Dilgeer, H. (1990). 'Cholo Muhnjay Chik Men', Sindhi Saahat Ghar, Hyderabad, Pp.67-70.

Gaad, G.M. (1984). 'Larkano Saah Sibhano', Pp.428, 473-477.

Jalal, Ayesha. (2012). 'The Oxford Companion To Pakistani History', Oxford University Press, Pp.6-7. 
Jatoi, H.B. (1955). 'Democracy or Dictatorship in Pakistan', Sindh Haari Committee Hyderabad Sindh.

Jatoi, H.B. (1957). 'Lands in Sindh who should own them', Sindh Haari Committee Hyderabad, Sindh.

Jatoi, H.B. (1960). 'Injustice to Sindh', Sindh Haari Committee, Hyderabad Sindh.

Jatoi, H.B. (1962). 'One Unit and Democracy', Sindh Haari Committee Hyderabad Sindh.

Jatoi, H.B. (2010). 'Shall Sindhi Language Stay in Karachi or not'?, Baba-eSindh Hyder Bux Jatoi Academy, Hyderabad, Pp.7-32.

Jatoi, H.B. (2012). 'Choond Ya Gunda Gardi Haari', Da-rul-Ishait Hyderabad Sindh, Pp.358-365.

Jatoi, H.B. (2012). 'Haari Geet', Sindh Haari Committee Hyderabad Sindh, Pp.252-308.

Jatoi, H.B. (2012). 'Haari Inqlaab', Sindh Haari Committee Hyderabad Sindh, Pp.23-25.

Jatoi, H.B. (2012). 'Haari Kahanyoun Haari', Da-rul-Ishait Hyderabad Sindh, Pp.191-248.

Jatoi, H.B. (2012). 'Zameendar Shahee Urf Kamdar Ja Karnama', Sindh Haari Committee Hyderabad Sindh, Pp.312-357.

Joyo, K. (2001). 'Ishiq, Hubulwatniaen Insaniyat', Sanyanh Publication, Hyderabad, Sindh, Pp.241-245.

Kazi, A. (2015). 'Comrade Hyder Bux Jatoi', Roshni Publication Kandiaro, Sindh, Pp.9-192.

Khuhro, H. (1999). 'The Making of Modern Sindh', Oxford University Press, pp.88-140.

Mehran Shair Number (1990). Sindhi Adabi Board, Jamshoro, Pp.488-494.

Muhammad, K.F. (1984). 'Haari Committee and Allottee Tahreek', Sindhi Saahat Ghar, Hyderabad, Pp.16-61.

Muhammad, K.F. (1999). 'Muhnjo Saffar', Sindhi Saahat Ghar, Hyderabad, Pp.246-265.

Pervez, I.H. (1984). 'The Contribution of Sindhi Muslims in Pakistan Movement', Institute of Sindhology, University of Sindh, Jamshoro, Sindh, p.51.

Qureshi, A.A. (2013). 'One Unit Aen Sindh', Peacock Publication Karachi, Pp.428, 473-477.

Rashdi, A.M. (1993). 'Uhay Deenhan Uhay Sheenhan', Sindhi Adabi Board Jamshoro, Pp.476-486.

Rashidi, S.H. (2010). 'Hoo Dothee Hoo Deenhn', Sindhi Adabi Board Jamshoro, p.32.

Saha, P.D. (1987). 'The Russian Revolution and the Indian Patriots', Manisha Publication, New Delhi, Pp.287-342.

Sannai, N. (2002). 'Maan Parado Sadd Jo', Naaz Sannai Foundation, Hyderabad, Sindh, Pp.21-34. 
Sham-ul-Hassan, K. (1992) 'Sindh's Fight for Pakistan', Sham-ul-Hassan Foundation For Historical Studies and Research Karachi, Sindh, p.155.

Solangi, A.H. (2007). 'Sindh Haari Committee: Taarikh and Jadodahad', Lab-eDarya Historical Society, Dokiri, Pp.52-54.

Soomro, I.I. (1990). Mehran Sawanai Number, Sindhi Adabi Board, Jamshoro, Pp.291-298.

Syed, G.M. (2010). 'Jannab Guzarium Jan Seen', G.M. Syed Academy Sunn, Pp.220-224.

Syed, G.M. (2011). ‘Kujh Khatt’, G.M. Syed Academy Sunn, Pp.287-289. 